\title{
Modified acrylamide copolymers as flocculants for model aqueous suspensions
}

\author{
Agnieszka Drzycimska, Beata Schmidt, Tadeusz Spychaj \\ Szczecin University of Technology, Polymer Institute, ul. Pulaskiego 10, 70-322 Szczecin, Poland, Tadeusz.Spychaj@ps.pl, \\ tel. (+48 91) 44942 47, fax (+48 91) 4494685
}

\begin{abstract}
Two groups of acrylamide copolymers have been obtained by inverse microemulsion polymerization using: (i) acrylamide (AAm) with [2-(acryloyloxy)ethyl]trimethylammonium chloride (AETAC) in the presence of sodium montmorillonite (MMT), and (ii) acrylamide with acrylic acid (AA) in the presence of aluminum sulphate. The received materials were characterised by capillary viscometry and the DSC methods, as well as the flocculation performances of the modified copolymers in the treatment of aqueous model suspensions of talc and calcium montmorillonite have been investigated. The effectiveness of the acrylamide flocculants was evaluated on the basis of the suspension extinction reduction and the sludge volume. The obtained results have been compared while using the modified materials and appropriate anionic and cationic AAm copolymers.
\end{abstract}

Keywords: anionic and cationic flocculants, acrylamide copolymers, inorganic modifier.

Presented at VII Conference Wasteless Technologies and Waste Management in Chemical Industry and Agriculture, Międzyzdroje, 12 - 15 June, 2007.

\section{INTRODUCTION}

Acrylamide (AAm) copolymerizes with vinyl monomers easily. These reactions often allow obtaining products having higher molecular weight than after homopolymerization ${ }^{\mathbf{1}}$. Some water soluble high molecular weight polymers are used as flocculants for fine-particle suspensions. Polyacrylamide and its copolymers are widely used in such a role in paper industry, mineral treatment processes, water treatment and sludge dewatering ${ }^{2-4}$. The flocculation performance depends on the type of the flocculant (neutral, positive or negative charge), its molecular weight, branching (length and degree) and on its content in water suspension ${ }^{5-7}$. Flocculation processes proceed due to charge neutralisation and bridging ${ }^{8}$. The separation by flocculation is effective and sufficient when the reduction in turbidity and faster particles settling are observed.

Development of industry and various types of wastewater contamination stimulate searching for new kinds of flocculants. To the new potentially interesting flocculant materials belong the systems composed of organic macromolecules and interacting inorganic substances. Such organic/inorganic flocculants can be obtained by a polymerization reaction in the presence of an inorganic modifier or due to the modification of the earlier synthesized hydrophilic polymers. Inorganic compounds in flocculation systems can perform various roles. Thanks to the use of montmorillonite there can be: (i) larger surface of organic/inorganic particle, (ii) faster rate of sedimentation, (iii) pollutants sorbed due to cation exchange, (iv) impurities penetrate into montmorillonite platelets. Aluminum cations in the polymerization system (AAm/acrylic acid) are bonded with carboxyl groups, thus cause an electrostatic-complex interaction between macromolecules in aqueous solutions, $\mathbf{9}$. Some new organic/inorganic systems based on aluminum hydroxide and polyacrylamide applied for kaolin flocculation have been recently described $^{11}$.

\section{EXPERIMENTAL}

\section{Material}

To receive cationic copolymer acrylamide ( $\sim 99 \%$, Fluka) and [2-(acryloyloxy)ethyl]trimethylammonium chloride (AETAC) (water solution, Ciba Specialty Chemicals Ltd.) were used. Sodium montmorillonite (MMT) was used as a modifier in the amount of 1 and $3 \mathrm{wt} . \%$. Anionic copolymers were synthesized using AAm and acrylic acid (AA) ( $~ 98 \%$, Aldrich). The molar ratio of AAm/comonomer was 0.9:0.1. The molar ratio of the metal cation $\left(\mathrm{Al}^{+3}\right)$ to carboxyl group of AAm/AA copolymer was $1: 30$ and $1: 3 . \mathrm{Al}_{2}\left(\mathrm{SO}_{4}\right)_{3} \cdot 18 \mathrm{H}_{2} \mathrm{O}(98 \%$, $\mathrm{POCh})$ the scheme of hybrid copolymers formation is given in Figure 1. The hypothetical structures for the $\mathrm{AAm} / \mathrm{AA} / \mathrm{Al}^{+3}$ system based on the molecular structure in glass-ionomer material $\left(\mathrm{AA} / \mathrm{Al}^{+3}\right)$ were discussed by Wilson and Crisp ${ }^{\mathbf{1 2}}$.

The reactions were carried out as heterogeneous, waterin-oil polymerization processes at $40 \pm 2{ }^{\circ} \mathrm{C}$, under nitrogen atmosphere, for 4 hours. The mixture of toluene ( $\geq 99.5 \%$, Chempur) and heptane (pure, POCh) $(3: 1 \mathrm{w} / \mathrm{w})$ was applied as the continuous phase. Azoisobutyronitrile (AIBN) purchased from POCh was used as a radical initiator.

As inorganic pollutants two minerals have been used: talc (Alfa, II Quality, Slovakia) and calcium montmorillonite (Bentonit SN, ZGM „Zębiec” S. A., Poland).

\section{PROCEDURE AND APPARATUS}

\section{Capillary viscometry}

The intrinsic viscosity values of the acrylamide copolymers and modified hybrid copolymers in aqueous solutions were compared on the basis of capillary viscometric measurements. Ubbelohde's viscometer with constants $\mathrm{K}=0.0484$ has been used; the measurements were carried out at $30 \pm 0.2{ }^{\circ} \mathrm{C}$, five times for each polymer solution. 
Intrinsic viscosity values were found using the following equation:

$[\eta]=\lim _{\mathrm{c} \rightarrow 0}\left[\left(\eta-\eta_{0}\right) / \eta_{0} \times \mathrm{c}\right]\left[\mathrm{cm}^{3} / \mathrm{g}\right]$

where: $\eta$-solution viscosity, $\eta_{0}$-water viscosity, c-concentration of polymer solution $\left[\mathrm{g} / \mathrm{cm}^{3}\right]$.

\section{Differential Scanning Calorimetry (DSC)}

Q100 DSC (TA Instruments Inc., USA) was used for the copolymers characterisation $\left(10^{\circ} \mathrm{C} / \mathrm{min}\right.$, from 35 to $\left.350{ }^{\circ} \mathrm{C}\right)$. Samples were weighted $(\sim 5 \mathrm{mg})$ into aluminum pans and hermetically sealed before analyses.

\section{Flocculation tests}

To prepare a model suspension an appropriate amount of the fine particle material (talc or calcium montmorillonite) was mixed with $1 \mathrm{dm}^{3}$ of distilled water, in a beaker. The required amount of the tested AAm copolymer was added into a beaker while stirring. The stirring was continued for $10 \mathrm{sec}$ at $400 \mathrm{rpm}$ after the addition of the copolymer solution. The stirring rate was then reduced to $50 \mathrm{rpm}$ and continued for $10 \mathrm{~min}$. The entire suspension was then transferred to a calibrated Imhoff funnel and allowed to settle down. Extinction of the aqueous phase has been measured using Specol 11 (Carl Zeiss Jena; wavelength $470 \mathrm{~nm}$ ) every 10 minutes over 2 hours. The volume of the settled deposit has been noted. Duplicate measurements under similar experimental conditions were carried out for the particular tested copolymers and for comparison without the flocculant (blind test).

\section{RESULTS AND DISCUSSION}

The results of viscometric measurements revealed that both synthesized unmodified AAm copolymers exhibited intrinsic viscosity values above $2000 \mathrm{~cm}^{3} / \mathrm{g}$ (Tab. 1), how-
Table 1. Intrinsic viscosity values of modified and unmodified acrylamide copolymers

\begin{tabular}{|l|c|}
\hline \multicolumn{1}{|c|}{ Modified copolymer } & $\begin{array}{c}\text { Intrinsic viscosity } \\
{\left[\mathrm{cm}^{3} / \mathrm{g}\right]}\end{array}$ \\
\hline $\mathrm{P}(\mathrm{AAm} / \mathrm{AETAC})$ & 2170 \\
\hline $\mathrm{P}(\mathrm{AAm} / \mathrm{AETAC}) / \mathrm{MMT} 1$ wt. $\%$ & 2370 \\
\hline $\mathrm{P}(\mathrm{AAm} / \mathrm{AETAC}) / \mathrm{MMT} 3 \mathrm{wt} \%$ & 2460 \\
\hline $\mathrm{P}(\mathrm{AAm} / \mathrm{AA})$ & 2480 \\
\hline $\mathrm{P}(\mathrm{AAm} / \mathrm{AA}) / \mathrm{Al}^{+3}\left(\mathrm{Al}^{+3} / \mathrm{COOH} \mathrm{1:30} \mathrm{mol} / \mathrm{mol}\right)$ & 610 \\
\hline $\mathrm{P}(\mathrm{AAm} / \mathrm{AA}) / \mathrm{Al}^{+3}\left(\mathrm{Al}^{+3} / \mathrm{COOH} \mathrm{1:3} \mathrm{mol} / \mathrm{mol}\right)$ & 280 \\
\hline
\end{tabular}

ever the value for the anionic copolymer $\mathrm{P}(\mathrm{AAm} / \mathrm{AA})$ exceeds the $[\eta]$ value for the cationic $\mathrm{P}(\mathrm{AAm} / \mathrm{AETAC})$ about ca. $14 \%$. The viscometric data proved that the addition of MMT both in 1 and $3 \mathrm{wt}$. \% to the copolymerizing system AAm/AETAC caused some increase of the $[\eta]$ values (ca. $9-13 \%)$. A higher $[\eta]$ value $\left(2460 \mathrm{~cm}^{3} / \mathrm{g}\right)$ has been found for the hybrid copolymer solution modified with the higher admixture of MMT. On the other hand, modification of anionic copolymer with $\mathrm{Al}^{+3}$ salt significantly reduced the intrinsic viscosity: ca. four times for the lower molar ratio of $\mathrm{Al}^{+3} / \mathrm{COOH}$ and nine times for the higher one. In the independent research $^{\mathbf{1 3}}$ it was found that the addition of the aluminum sulfate salt to the aqueous solution of AAm or its mixture with AA retards the (co)polymerization reaction; as a result a decrease of intrinsic viscosity of the copolymer $\mathrm{AAm} / \mathrm{AA} / \mathrm{Al}^{+3}$ was observed.

Heat flow thermographs from DSC measurements (Fig. 2) exhibit that the presence of inorganic modifiers in the hybrid AAm copolymers causes shifting maxima of exothermic peaks in a lower temperature range: into higher values for AAm/AETAC/MMT copolymers, and into lower values for the $\mathrm{AAm} / \mathrm{AA} / \mathrm{Al}^{+3}$ ones. Respectively, the increase of MMT content in the cationic copolymer, causes higher displacement of maximum [from $131.7{ }^{\circ} \mathrm{C}$ for the unmodified copolymer AAm/AETAC, through $145.8^{\circ} \mathrm{C}$,
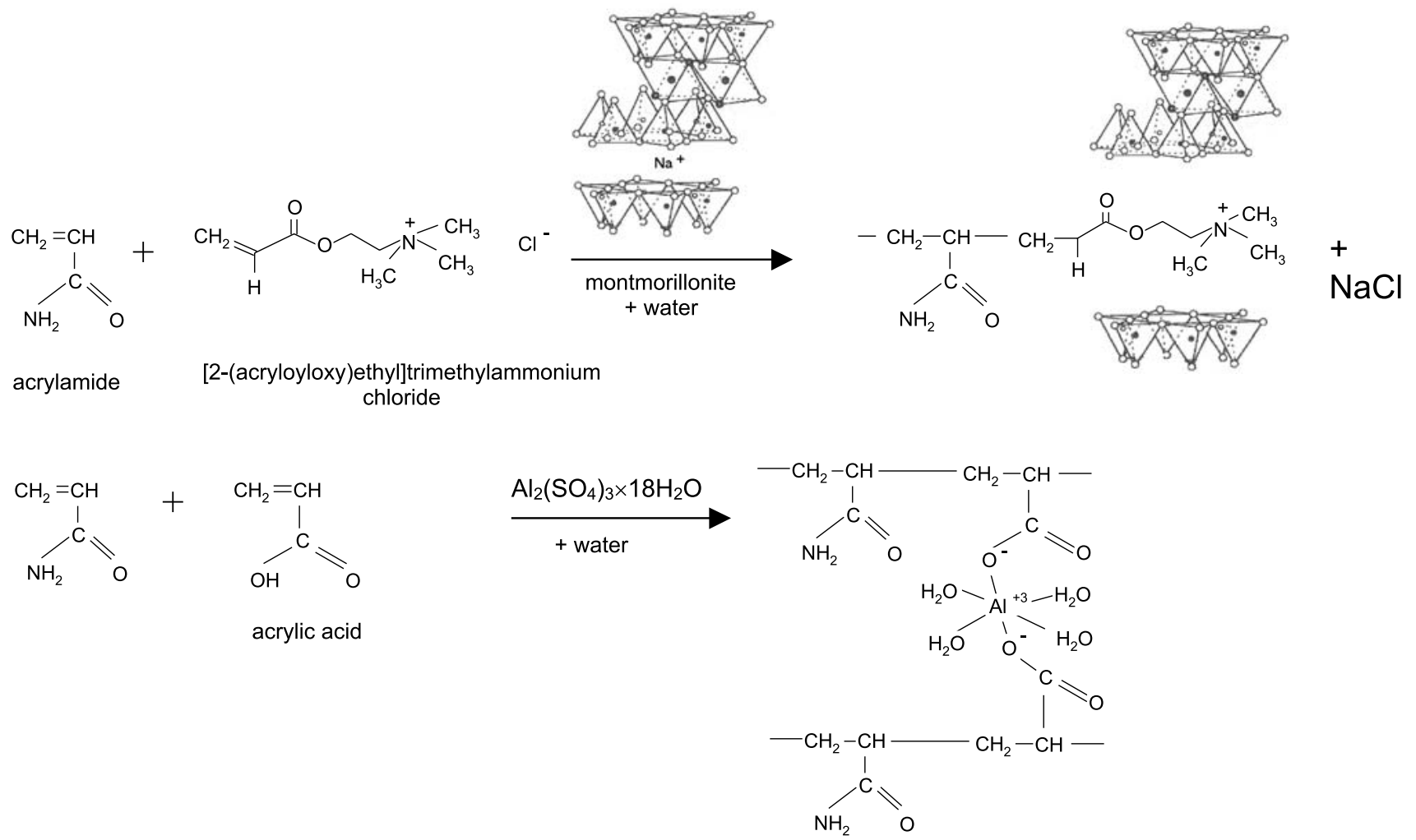

Figure 1. A scheme of hybrid AAm copolymers formation 


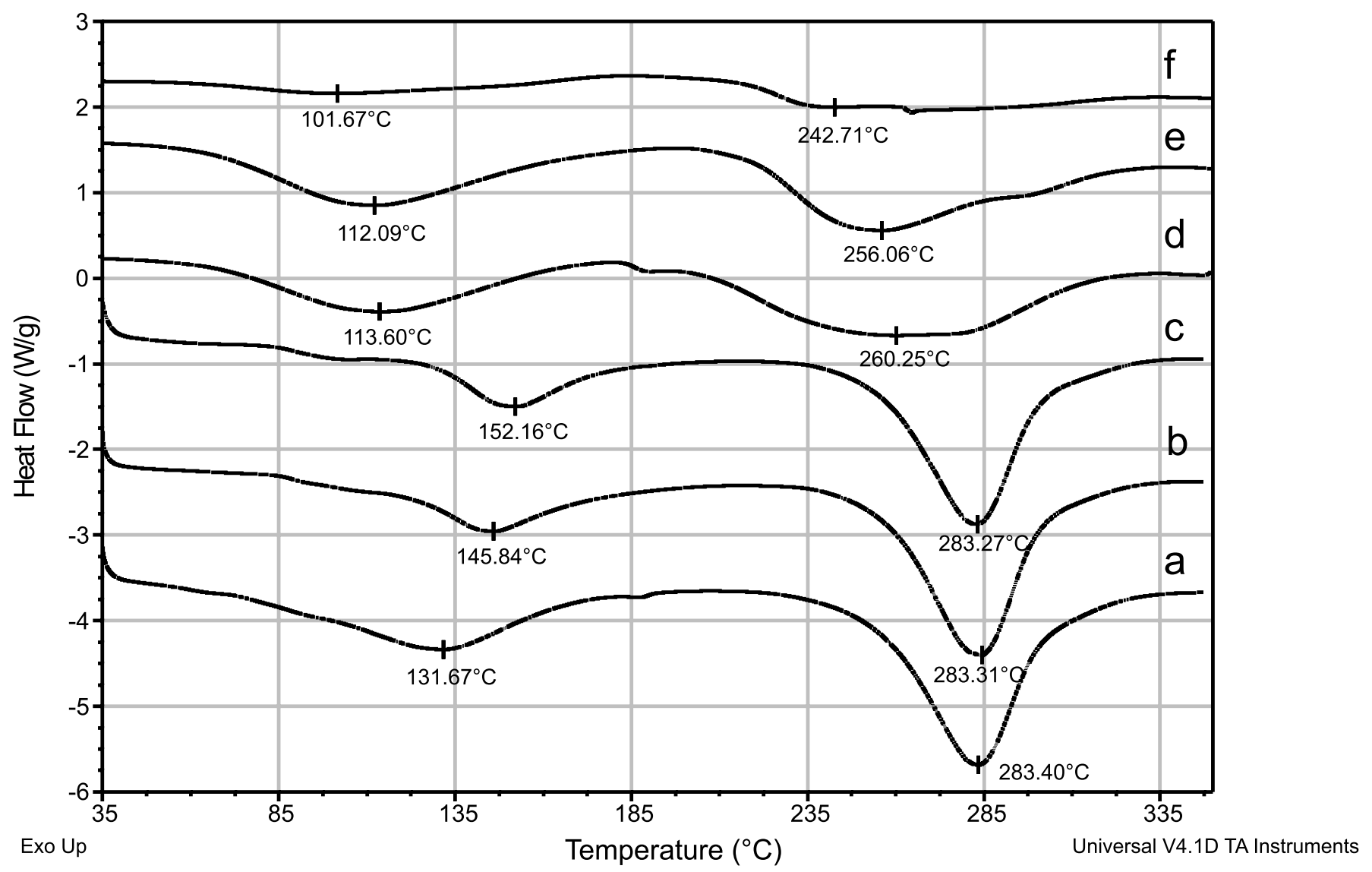

Figure 2. The DSC thermograms of the acrylamide copolymers: a - P(AAm/AETAC), b - P(AAm/AETAC)/MMT 1 wt. \%, $\mathrm{c}-\mathrm{P}(\mathrm{AAm} / \mathrm{AETAC}) / \mathrm{MMT} 3$ wt. $\%$, d - P(AAm/AA), e - P(AAm/AA)/Al ${ }^{+3}\left(\mathrm{Al}^{+3} / \mathrm{COOH} 1: 30 \mathrm{~mol} / \mathrm{mol}\right), \mathrm{f}-\mathrm{P}(\mathrm{AAm} /$ $\mathrm{AA}) / \mathrm{Al}^{+3}\left(\mathrm{Al}^{+3} / \mathrm{COOH} 1: 3 \mathrm{~mol} / \mathrm{mol}\right)$

up to $152.2^{\circ} \mathrm{C}$ for $\mathrm{P}(\mathrm{AAm} / \mathrm{AETAC})$ modified with $3 \mathrm{wt}$. $\%$ MMT]. For the set of the AAm/AA copolymers the respective maximum is shifted from $113.6{ }^{\circ} \mathrm{C}$ for the unmodified $\mathrm{P}(\mathrm{AAm} / \mathrm{AA})$ up to $101.7^{\circ} \mathrm{C}$ for $\mathrm{P}(\mathrm{AAm} /$ $\mathrm{AA}) / \mathrm{Al}^{+3}-$ for the higher aluminum content $\left(\mathrm{Al}^{+3} / \mathrm{COOH}\right.$ $=1: 3 \mathrm{~mol} / \mathrm{mol}$ ).

The results of jar tests of the talc suspension flocculation on the basis of extinction measurements are presented in Figure 3. The concentrations of the two tested AAm copolymer systems were: $0.75 \mu \mathrm{g} / \mathrm{cm} 3$ (Fig. 3a) and $4.5 \mu \mathrm{g}$ / $\mathrm{cm}^{3}$ (Fig. 3b). Figure 4 shows sludge volumes found during the same flocculation experiments. As it may be seen in Fig. 3 both modified series of copolymers exhibit flocculation effectiveness with the exception of $\mathrm{P}(\mathrm{AAm} /$ $\mathrm{AA}) / \mathrm{Al}^{+3}\left(\mathrm{Al}^{+3} / \mathrm{COOH} 1: 30 \mathrm{~mol} / \mathrm{mol}\right)$ for the copolymer dose $0.75 \mu \mathrm{g} / \mathrm{cm}^{3}$ (Fig. 3a). Generally, better results in the reduction of extinction for talc suspension are caused by modified cationic copolymers. In these cases extinction is reduced over 10 times (Fig. 3a) as compared to the values of the untreated suspension. It should be mentioned that the unmodified $\mathrm{P}(\mathrm{AAm} / \mathrm{AETAC})$ copolymer acts worse than montmorillonite containing hybrids - for their lower doses $\left(0.75 \mu \mathrm{g} / \mathrm{cm}^{3}\right)$. For higher flocculant dose (Fig. $3 \mathrm{~b}$ ) the extinction reduction is even higher up to ca. 0.02 in comparison with ca. 0.3 for the untreated suspension. The set of tested anionic copolymers in their higher concentration - reduce the extinction of talc suspension from ca. 0.3 to ca. 0.18 (Fig. 3b). The best reduction in suspension turbidity among anionic copolymers has been achieved applying $\mathrm{P}(\mathrm{AAm} / \mathrm{AA})$ and $\mathrm{P}(\mathrm{AAm} /$ $\mathrm{AA}) / \mathrm{Al}^{+3}\left(\mathrm{Al}^{+3} / \mathrm{COOH} 1: 3 \mathrm{~mol} / \mathrm{mol}\right)$. However, these results are substantially worse than those for the $\mathrm{P}(\mathrm{AAm} /$ AETAC)/MMT copolymers.

The volume of sludge for the untreated talc suspension is $9 \mathrm{~cm}^{3}$ (Fig. 4), keeping in mind that a great amount of mineral filler is still in suspension. After suspension treatment the sludge volume has been larger then that for the

a
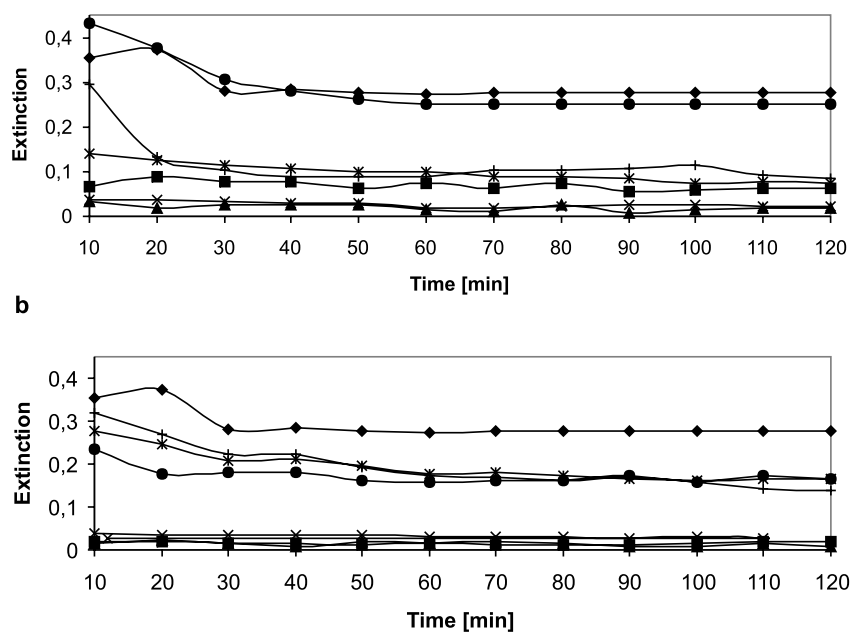

$\longrightarrow$ untreated suspension

$\neg$ P(AAm/AETAC)/MMT 1 wt. \%

$\rightarrow$ - $P(A A m / A E T A C)$

* P(AAm/AA)

$\rightarrow$ P(AAm/AETAC)/MMT 3 wt. \%

— $\mathrm{P}(\mathrm{AAm} / \mathrm{AA}) / \mathrm{Al}^{+3}\left(\mathrm{Al}^{+3} / \mathrm{COOH} 1: 3 \mathrm{~mol} / \mathrm{mol}\right)$

Figure 3. Dependence of extinction for talc aqueous suspension as a function of time for the tested acrylamide copolymers: $\mathbf{a}$ - dose $0.75 \mu \mathrm{g} / \mathrm{cm}^{3}, \mathbf{b}-$ dose $4.5 \mu \mathrm{g} / \mathrm{cm}^{3}$ 
Table 2. The sludge volumes and extinction changes during flocculation tests for Ca-montmorillonite aqueous suspension as a function of acrylamide copolymer type and dose

\begin{tabular}{|c|c|c|c|c|c|c|c|c|}
\hline \multirow{2}{*}{ Type of acrylamide copolymer } & \multirow{2}{*}{\multicolumn{2}{|c|}{$\begin{array}{l}\text { Sludge volume } \\
{\left[\mathrm{cm}^{3}\right]}\end{array}$}} & \multicolumn{6}{|c|}{ Extinction after time [min] } \\
\hline & & & 10 & 30 & 120 & 10 & 30 & 120 \\
\hline Flocculant concentration $\left[\mu \mathrm{g} / \mathrm{cm}^{3}\right]$ & 0.75 & 4.50 & \multicolumn{3}{|c|}{0.75} & \multicolumn{3}{|c|}{4.50} \\
\hline Untreated suspension & \multicolumn{2}{|c|}{16} & 1.16 & 0.86 & 0.38 & 1.16 & 0.86 & 0.38 \\
\hline P(AAm/AETAC) & 31 & 44 & 0.38 & 0.21 & 0.19 & 0.05 & 0.02 & 0.01 \\
\hline $\mathrm{P}(\mathrm{AAm} / \mathrm{AETAC}) / \mathrm{MMT} 1$ wt. \% & 30 & 39 & 0.42 & 0.23 & 0.16 & 0.04 & 0.05 & 0.04 \\
\hline $\mathrm{P}(\mathrm{AAm} / \mathrm{AETAC}) / \mathrm{MMT} 3$ wt. $\%$ & 27 & 35 & 0.92 & 0.51 & 0.28 & 0.09 & 0.07 & 0.07 \\
\hline $\mathrm{P}(\mathrm{AAm} / \mathrm{AA})$ & 20 & 19 & 0.94 & 0.79 & 0.50 & 1.21 & 0.99 & 0.73 \\
\hline 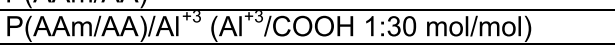 & 14 & 13 & 1.07 & 0.64 & 0.45 & 1.05 & 0.65 & 0.37 \\
\hline $\mathrm{P}(\mathrm{AAm} / \mathrm{AA}) / \mathrm{Al}^{+3}\left(\mathrm{Al}^{+3} / \mathrm{COOH} 1: 3 \mathrm{~mol} / \mathrm{mol}\right)$ & 22 & 21 & 0.93 & 0.60 & 0.23 & 0.92 & 0.63 & 0.28 \\
\hline
\end{tabular}

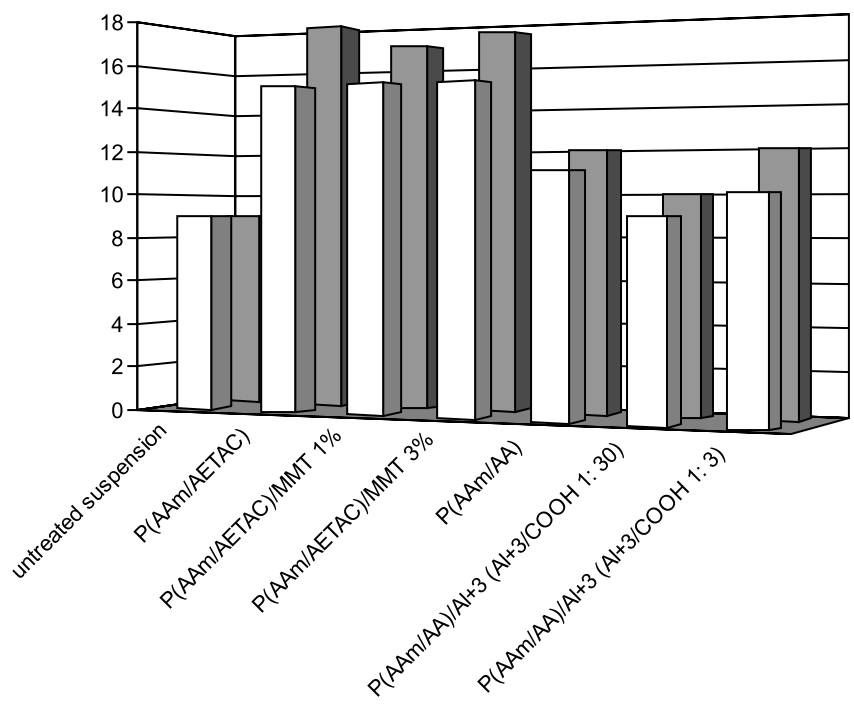

Figure 4. Dependence of sludge volume for talc aqueous suspension on acrylamide copolymer type and dose $\left(0.75 \mathrm{mg} / \mathrm{cm}^{3}\right.$ - white, $4.50 \mathrm{mg} / \mathrm{cm}^{3}$ - dark $)$

untreated system. Two various phenomena influence the observed resultant effect, i.e.: (i) the increasing amount of the sedimented deposit, and (ii) the increasing hydrophilicity of the deposit containing the flocculating AAm copolymers. The increase in the flocculant dose causing increase in sludge volume for all the tested copolymers is in accordance with the above statements. The largest deposit volume for the tested cationic copolymers has been observed (twice as large as for the untreated suspension). Appropriately, for the anionic copolymers $\left[\mathrm{P}(\mathrm{AAm} / \mathrm{AA})\right.$ and $\mathrm{P}(\mathrm{AAm} / \mathrm{AA}) / \mathrm{Al}^{+3}\left(\mathrm{Al}^{+3} / \mathrm{COOH} 1: 3\right.$ $\mathrm{mol} / \mathrm{mol})] 30 \%$ increase of the sludge volumes has been noted.

Table 2 compiles the extinction and sludge volume changes during flocculation tests for the Ca-MMT suspension. A great majority of the tested copolymers has reduced the turbidity of this suspension. In the case of the Ca-MMT flocculation tests, the best results has been found when using the unmodified $\mathrm{P}(\mathrm{AAm} / \mathrm{AETAC})$ among the cationic copolymers and the $\mathrm{P}(\mathrm{AAm} / \mathrm{AA})$ modified with higher concentration of aluminum salt $\left(\mathrm{Al}^{+3} / \mathrm{COOH} 1: 3\right.$ $\mathrm{mol} / \mathrm{mol}$ ). The efficiency of the first cationic copolymer is obvious, because cation exchange between calcium montmorillonite mineral particles and quaternary ammonium cations ${ }^{14}$ of the copolymer macromolecules will enhance this suspension settlement. The respective extinctions were reduced from 1.16 to level 0.01 for that cationic copolymer and to 0.28 for anionic ones (dose 4.5 $\mu \mathrm{g} / \mathrm{cm}^{3}$ ). All tested flocculants caused an increase of sludge volume in comparison to the untreated suspension, besides copolymer $\mathrm{P}(\mathrm{AAm} / \mathrm{AA}) / \mathrm{Al}^{+3}$ with lower salt content $\left(\mathrm{Al}^{+3} / \mathrm{COOH} 1: 30 \mathrm{~mol} / \mathrm{mol}\right)$.

\section{CONCLUSIONS}

Modification of cationic acrylamide copolymer with sodium montmorillonite slightly increases the intrinsic viscosity values, which relates to the improvement of the flocculation effectiveness. In spite of reduction in the intrinsic viscosities for the modified $\mathrm{AAm} / \mathrm{AA} / \mathrm{Al}^{+3}$ copolymers (shorter macromolecules), they may exhibit acceptable flocculation effectiveness. It may be considered that such a feature can be explained as a cumulative effect of the special properties of organic AAm copolymer (flocculant) and inorganic aluminum salt (coagulant).

Synthesized hybrid acrylamide copolymers modified with inorganic compounds can be used as flocculants in wastewater treatment processes. The efficiency of such hybrid flocculants can exceed or represent a similar standard as the conventional acrylamide flocculants.

\section{ACKNOWLEDGEMENTS}

The first author (A.D.) appreciates financial support of a part of this contribution (funds for science MNiSzW: project N205 067 32/3784).

\section{LITERATURE CITED}

(1) Thomas W. M., Wei Wang D.: Acrylamide polymers, in Encyclopedia of Polymer Science and Engineering (Ed. Mark H. F.), vol. 1, Wiley-Interscience, New York 1985, 169.

(2) Qian J. W., Xiang X. J., Yang W. Y., Wang M., Zheng B. Q.: Flocculation performance of different polyacrylamide and the relation between optimal dose and critical concentration, European Polymer Journal, 2004, 40, 1699.

(3) Radoiu M. T., Martin D. I., Calinescu I., Iovu H.: Preparation of polyelectrolytes for wastewater treatment, Journal of Hazardous Materials, 2004, 106B, 27.

(4) Wong S. S., Teng T. T., Ahmad A. L. , Zuhairi A., Najafpour G.: Treatment of pulp and paper mill wastewater by polyacrylamide (PAM) in polymer induced flocculation, Journal of Hazardous Materials, 2006, 135, 378.

(5) Mpofu P., Addai-Mensah J., Ralston J.: Investigation of the effect of polymer structure type on flocculation, rheology and dewatering behaviour of kaolinite dispersions, International Journal of Mineral Processing, 2003, 71, 247.

(6) Abraham T.: Role of polyelectrolyte charge density in tuning colloidal forces, AIChE Journal, 2004, 50, 2613.

(7) Hocking M. B., Klimcuk K. A., Lowen S.: Watersoluble acrylamide copolymers. X. Flocculation efficiencies of poly[acrylamide-co-N,N-dimethylacrylamide], poly[acrylamide-co-methacrylamide], poly[acrylamide-co-N-t- 
butylacrylamide], and their cationic derivatives, Journal of Applied Polymer Science, 2001, 84, 2090.

(8) Fan A., Turro N. J., Somasundaran P.: A study of dual polymer flocculation, Colloids and Surfaces, 2000, 161, 141.

(9) Drzycimska A., Schmidt B., Spychaj T.: (Ko)poliakryloamidowe flokulanty nano-hybrydowe, Mat. Konf.: VIII Konferencja „Otrzymywanie, zastosowanie i analiza wodnych dyspersji i roztworów polimerów”, 13 - 14 października 2005, Szczyrk, 53 - 59.

(10) Spychaj T., Schmidt B.: Polymeric systems based on poly(acrylic acid) and trivalent metal cations, Macromolecular Symposia, 2000, 152, 173.

(11) Yang W. Y., Qian J. W., Shen Z. Q.: A novel flocculant of $\mathrm{Al}(\mathrm{OH})^{3}$-polyacrylamide ionic hybrid, Colloid and Interface Science, 2004, 273, 400.

(12) Wilson A. D. , Crisp S.: Organolithic macromolecular materials, Applied Science Publishers LTD, London, 1997, 136.

(13) Drzycimska A., Spychaj T.: Estimation of the aluminum salt effect on homopolymerization of acrylamide and its copolymerization with acrylic acid by DSC, Polimery, 2006, 51, 460.

(14) Kowalczyk K., Spychaj T.: Wodorozcieńczalne epoksydowe kompozycje powłokowe modyfikowane nanocząstkami, Przemysł Chemiczny, 2006, 85, 927. 